\title{
Factors Related to Infant Mortality Rate and Under-Five Mortality Rate in Turkey: An Ecological Study with Provincial Data
}

\section{Türkiye'de Bebek Ölüm Hızı ve Beş Yaş Altı Çocuk Ölüm Hızıyla Iilişkili Etmenler: ill Verileriyle Ekolojik Bir Araştırma}

\author{
Hakan Tüzün ${ }^{1}$ (D) \\ ${ }^{1}$ Gazi University, Faculty of Medicine, Department of Public Health, Ankara, Turkey
}

ORCID ID: H.T. 0000-0002-6376-8979

Citation/Atff: Tuzun H. Factors related to ınfant mortality rate and under-five mortality rate in Turkey: An ecological study with provincial data. Çocuk Dergisi - Journal of Child 2021;21(3):221-230. https://doi.org/10.26650/jchild.2021.993630

ABSTRACT

Objective: To determine the factors related to the infant mortality rate (IMR) and under-five mortality rate (U5MR) in Turkey.

Material and Methods: An ecological study was conducted using the provincial data of the Turkish Statistical Institute (TURKSTAT) and the Ministry of Health.

Results: IMR and U5MR ( $r$ values for these two parameters are respectively mentioned in parenthesis) had a statistically significant relationship with total fertility rate (TFR) ( $r=0.661$ and 0.718$)$, ratio of adolescent births to total births ( $r=0.542$ and 0.587 ), gross domestic product (GDP) per capita ( $r=-0.555$ and -0.591 ), proportion of women aged $\geq 18$ with high school or higher education ( $r=-0.434$ and -0.470$)$, number of physicians per $100,000$ people ( $r=-0.352$ and -0.398$)$, number of hospital beds per 100,000 people ( $r=-0.244$ and -0.286 ), and number of newborn intensive care beds per thousand births ( $r=-0.324$ and -0.359$)$.

In bivariate models for IMR, the effect of all of the abovementioned parameters on the model was statistically significant, except for the number of hospital beds per 100,000 people. In bivariate models for U5MR, the effect of all the above-mentioned parameters on the model was statistically significant. TFR was the only variable with a statistically significant effect on the multivariate model for both IMR (standardized $\beta=0.621, R^{2}=0.385$ ) and U5MR (standardized $\beta=0.667, R^{2}=0.445$ ).

Conclusion: The results showed the presence of a weak correlation for the variables related to the numbers of healthcare professionals and hospital beds, thereby indicating that the effect of healthcare service provision is rather indirect. Health promotion programs can be developed for infant and child mortality with the aim of changing high fertility preferences and preventing adolescent pregnancies. Economic policies that improve income distribution and initiatives to increase education levels of girls can be life-saving for infants and children.

Keywords: Infant mortality rate, under-five mortality rate, ecological study, determinants of health
ÖZ

Amaç: Türkiye'de bebek ölüm hızı (BÖH) ve beş yaş altı ölüm hızı (BYAÖH) ile ilişkili etmenleri saptamak amaçlanmıştır.

Gereç ve Yöntemler: Türkiye İstatistik Kurumu (TÜiK) ve Sağlık Bakanlığının il bazlı verileri kullanılarak ekolojik tipte bir araştırma yapılmıştır.

Bulgular: BÖH ve BYAÖH'nin ( $r$ değerleri bu iki parametre için sırası ile belirtilmiştir), toplam doğurganlık hızı (TDH) $(r=0,661 / r=0,718)$, adölesan doğumların toplam doğumlar içindeki oranı $(r=0,542 / r=0,587)$, kişi başı Gayrisafi Yurt İçi Hasıla (GYSH) ( $r=-0,555 / r=-0,591), 18$ yaş ve üzeri için lise ve üzeri eğitim alan kadınların oranı $(r=-0,434 / r=-0,470)$, yüz bin kişiye düşen hekim sayısı ( $r=-0,352 / r=-0,398)$, yüz bin kişiye düşen hastane yatak sayısı ( $r=-0,244 / r=-0,286)$, bin doğuma düşen yeni doğan yoğun bakım yatak sayısı $(r=-0,324 / r=-0,359)$ ile istatistiksel olarak anlamlı ilişkisi vardır.

BÖH için iki değişkenli modellerde, yüz bin kişiye düşen hastane yatak sayısı haricinde yukarıda belirtilen parametrelerin tümünün modele etkisi istatistiksel olarak anlamlıdır. BYAÖH için iki değişkenli modellerde yukarıda belirtilen parametrelerin tümünün modele etkisi istatistiksel olarak anlamlıdır. TDH, Hem BÖH (standardize $\beta=0,621, R^{2}=0,385$ ) hem de BYAÖH (standardize $\beta=0,667, R^{2}=0,445$ ) için çok değişkenli modele etkisi istatistiksel olarak anlamlı bulunan tek değişkendir.

Sonuç: Sağlık insan gücü ve yatak sayısı ile ilişkili değişkenler için zayıf ilişki saptanması, sağlık hizmet sunumunun etkisinin daha dolaylı olduğunu göstermektedir. Bebek ve çocuk ölümlerine yönelik sağlığı geliştirme programları, yüksek doğurganlık tercihlerini değiştirmeye ve adölesan gebelikleri önlemeye yönelik olarak geliştirilebilir. Gelir dağılımını düzeltici ekonomi politikaları ve kız çocuklarının eğitimini artırmaya yönelik girişimler, bebekler ve çocuklar için hayat kurtarıcı olabilir.

Anahtar Kelimeler: Bebek ölüm hızı, beş yaş altı ölüm hızı, ekolojik araştırma, sağlığın belirleyicileri

Corresponding Author/Sorumlu Yazar: Hakan Tüzün E-mail: drtuzunh@yahoo.com

Submitted/Başvuru: 10.09.2021 • Revision Requested/Revizyon Talebi: 20.10.2021 • Last Revision Received/Son Revizyon: 25.10 .2021 •

Accepted/Kabul: 12.11.2021 


\section{INTRODUCTION}

Mortality during infancy and childhood continues to be a public health problem, despite the fact that there have been several remarkable improvements over time. The worldwide under-five mortality rate (U5MR) declined from 93 per thousand (12.6 million deaths) in 1990 to 38 per thousand (5.2 million deaths) in 2019 (1). Infant mortality rate (IMR) decreased from 65 per thousand ( 8.7 million deaths) in 1990 to 29 per thousand (4.0 million deaths) in 2018 (2). Notably, a significant majority of these deaths are due to preventable and treatable causes such as preterm birth complications, perinatal asphyxia, birth traumas, pneumonia, diarrhea, and malaria (1).

In Turkey, IMR was approximately 200, 130, and 80 per thousand in the late 1950s, mid-1970s, and mid-1980s, respectively. In TDHS (Turkey Demographic and Health Survey) for the years 2003-2008 and 2013, IMR was respectively 29, 17 , and 13 per thousand, whereas U5MR was found to be 37 , 24, and 15 per thousand, respectively (3). According to the data from the Ministry of Health, IMR was 9.0 per thousand in 2019 in Turkey. Currently, IMR in Turkey is below the global average (28.2 per thousand); however, it is above the figures for the WHO (World Health Organization) European region (6.1 per thousand), OECD (Organization for Economic Cooperation and Development) (3.7 per thousand), and the EU (European Union) (3.2 per thousand) (4). U5MR was 11.1 per thousand in 2019 in Turkey, which is below the global average (37.7 per thousand) but above the WHO European region (7.1 per thousand), OECD (4.4 per thousand), and the EU (3.9 per thousand) (4).

Infant and child mortality are among the most basic parameters for revealing the healthcare level and evaluating the outcomes of healthcare services in a country (5). Targets of the 2030 Agenda for Sustainable Development include reducing the neonatal infant mortality rate to 12 per thousand and reducing the U5MR to 25 per thousand (6). In Turkey, IMR and U5MR are among the key performance indicators in the Ministry of Health's 2019-2023 Strategic Plan. Targets for the end of the Plan period have been determined to be 8.5 per thousand for IMR and 10.6 per thousand for U5MR (7).

Despite these developments, several inequalities between countries and regions in terms of infant and child mortality remain. IMR in the WHO Africa region (52 per thousand) is more than 7 times higher than that in the WHO European region (7.1 per thousand) (2). Sub-Saharan Africa and central and southern Asia have $52 \%$ of the world's under-five population, but $80 \%$ of the world's under-five deaths occur in these regions (1). There are also geographical inequalities in infant and child mortality within countries. A study examining under-five deaths in 99 low- and middle-income countries revealed intercountry geographic inequalities, which were as high as up to seven-fold in the case of Vietnam. The study revealed that if geographic inequalities could be avoided, $58 \%$ of the child deaths that occurred between 2000 and 2017 could have been prevented in the countries examined (8). Regional inequalities in infant and child mortality also exist in Turkey. According to NUTS 1
(Nomenclature of Territorial Units for Statistics), IMR is 13.5 per thousand in Southeast Anatolia, where it has the highest value, whereas it is 5.9 per thousand in the Eastern Black Sea region, where it has the lowest value. U5MR is 16.9 per thousand in Southeast Anatolia, where it has the highest value, while it is 7.3 per thousand in the Eastern Black Sea region, where it has the lowest value (4).

Social determinants may reportedly be more important than healthcare services or lifestyle choices in influencing health. It has been estimated that the effects of areas outside the healthcare sector are more significant than the effects of the healthcare sector on health. Studies reveal that $30 \%-55 \%$ of health outcomes can be attributed to social determinants (9). Infancy and childhood mortality rates are significantly higher among lower socioeconomic groups. Factors most closely associated with childhood mortality, including malnutrition, exposure to infections, and healthcare service use have been reported to be worse among deprived groups (10). Factors associated with infant mortality are variables that can be grouped under the headings of medical, demographic, and socioeconomic variables, including variables such as maternal age, parity, and mother's diseases such as diabetes/ anemia/preeclampsia, as well as variables such as education, employment status, and social security of the mother (11).

Ecological studies are studies conducted by investigators based on data belonging to groups, and not directly based on data obtained from individuals within the scope of the study (12). Therefore, comparison-in-analysis is a comparison made based on groups, and not on singular individuals. The challenges resulting from time and resource constraints that are associated with conducting studies involving a large number of individuals can be overcome with ecological studies (13). The advantage of ecological studies is that data obtained from societies with different characteristics or from different data sources can be used (14).

In the national literature, it is observed that the current studies using the ecological method for factors associated with IMR and U5MR are very limited. These studies consist of a study based only on data from Eskişehir province and a study based on national data from 1997 or the closest previous period $(15,16)$. Revealing the current socioeconomic factors associated with IMR and U5MR in Turkey may lead to results that are guiding for policies and intervention initiatives aimed at reducing mortality. The aim of this study was to determine the factors related to IMR and U5MR based on provincial data from TURKSTAT (Turkish Statistical Institute) and the Ministry of Health.

\section{MATERIAL AND METHODS}

\section{Data Sources and Variables}

The Ministry of Health Statistics Yearbook 2019 was used for the data source from the Ministry of Health, as it contains the most up-to-date data disclosed to the public (4). For other data sources, the researcher aimed to use the data from a period closest to 2019. The data for the year 2019 from TURKSAT (Turkish Statistical Institute) were taken from the "provincial 
indicators" and "central distribution system" datasets (17, 18). Since the latest statistical report published by the General Directorate of Public Hospitals was from 2017, the data from this report was used as a source (19).

The dependent and independent variables and data sources within the scope of the study are shown in Table 1.

The categories of "high school or equivalent vocational school," "college or university," "master's degree," and "PhD" in the TURKSTAT dataset were included in the calculation of the proportion of women aged $\geq 18$ who received high school or higher education $(17,18)$. The rural population ratio is defined as "the ratio of the population living in places with a population of 20,000 and below to the total population" in the Statistics Yearbook of the Ministry of Health (4).

\section{Statistical method}

The conformity of the data to normal distribution was evaluated with the Kolmogorov Smirnov test. IMR, which was one of the dependent variables examined, did not conform to normal distribution $(p=0.009)$. However, U5MR was normally distributed $(p=0.163)$. Among the independent variables examined, the population per family medicine unit $(p=0.200)$ and the number of patient beds per 100,000 people $(p=0.073)$ were the normally distributed variables. Other independent variables were not found to be normally distributed. Most of the independent variables examined did not conform to normal distribution, and Spearman's test, which is a non-parametric method, was used in all correlation analyses in order to use the same analysis method for all variables.

Reportedly, there is a strong relationship when the correlation coefficient ( $r$ ) between two variables is higher than 0.7 or 0.8 $(20,21)$. In this study, it was suggested that the independent variables with correlation coefficients $(r)<0.70$ within themselves should be included in the linear regression model.

Bivariate linear regression models were created with IMR and U5MR for the independent variables, for which a statistically significant relationship was found in the correlation analysis. Then, a multivariate linear regression model was created for IMR and U5MR, including all independent variables that were found to have a statistically significant relationship in the correlation analysis.

IMR, which was one of the two dependent variables considered in the study, did not conform to normal distribution. The natural logarithmic method (Napierian Logarithm), which is used in the creation of linear regression models of non-normally distributed variables, was used for both IMR and U5MR to allow for a standardized evaluation of the analysis results of two dependent variables. The purpose of using this method in linear regression analysis is to adapt the dependent variables to normal distribution $(15,22)$.

While creating the multivariate regression model, the "stepwise regression" method was used as the "variable selection method." Statistical significance was considered at $p<0.05$.

\section{Scope of ethical approval}

Since public datasets were used in this ecological study, it is outside the scope of ethics committee approval.

\section{RESULTS}

The provinces with the lowest IMR in Turkey are Karabük (3 per thousand), Giresun (4.7 per thousand), Bartin (4.8 per thousand), Yalova (5.5 per thousand), and Kütahya (5.8 per thousand). The provinces with the highest IMR are Hakkari (14.1 per thousand), Nevşehir (14.1 per thousand), Kırşehir (14.2

Table 1: Variables and data sources within the scope of the study

\begin{tabular}{|c|c|c|}
\hline Variable & Data source & Year \\
\hline \multicolumn{3}{|l|}{ Dependent variables } \\
\hline Infant mortality rate (per thousand) & TURKSTAT & 2019 \\
\hline Under-5 mortality rate (per thousand) & TURKSTAT & 2019 \\
\hline \multicolumn{3}{|l|}{ Independent variables } \\
\hline Proportion of women aged 18 and over with high school or higher education (percent) & TURKSTAT & 2019 \\
\hline Ratio of municipal population served by a sewerage network to total municipal population (\%) & TURKSTAT & 2019 \\
\hline Rural population ratio (percent) & MoH Statistics Yearbook & 2019 \\
\hline Number of physicians per 100,000 people & MoH Statistics Yearbook & 2019 \\
\hline Population per family medicine unit & MoH Statistics Yearbook & 2019 \\
\hline Number of hospital beds per 100,000 people & MoH Statistics Yearbook & 2019 \\
\hline Number of newborn intensive care beds per thousand births & Statistical Report of KHGM & 2017 \\
\hline Total fertility rate (per thousand) & TURKSTAT & 2019 \\
\hline Ratio of adolescent births to total births(percent) & TURKSTAT & 2019 \\
\hline
\end{tabular}

TURKSTAT: Turkish Statistical Institute, KHGM: General Directorate of Turkish Public Hospitals, MoH: Ministry of Health, GDP: gross domestic product 
per thousand), Şanlıurfa (15.3 per thousand), and Gaziantep (16.2 per thousand). The provinces with the lowest U5MR are Karabük (3.0 per thousand), Giresun (5.7 per thousand), Bilecik (6.7 per thousand), Bartin (6.9 per thousand), and Artvin (7.2 per thousand). The provinces with the highest U5MR are Siirt (16.2 per thousand), Kırşehir (16.7 per thousand), Hakkari (16.9 per thousand), Gaziantep (19.1 per thousand), and Şanlıurfa (19.6 per thousand). Table 2 shows the values of dependent and independent variables indicated in the data sources for Turkey and the median values calculated based on provincial data.

Table 3 shows the results of the correlation analyses between IMR and U5MR and independent variables. The variables that were not found to have a statistically significant relationship with either IMR or U5MR were the ratio of the municipal population served by the sewerage network to the total municipal population, the rural population ratio, and the population per family medicine unit $(p>0.05)$.
There was a statistically significant positive relationship between both IMR and U5MR and total fertility rate (TFR) $(p<0.01)$ and the ratio of adolescent births to total births $(p<0.01)$. Both IMR and U5MR had a significantly negative statistical relationship with gross domestic product (GDP) per capita $(p<0.01)$, proportion of women aged $\geq 18$ with high school or higher education $(p<0.01)$, number of physicians per 100,000 people $(p<0.01)$, number of hospital beds per 100,000 people ( $p<0.05$ for IMR and $p<0.01$ for U5MR), and number of newborn intensive care beds per thousand births $(p<0.01)$ (Table 3).

When a correlation analysis was performed for all independent variables, which were found to be statistically significant in the correlation analysis with IMR and U5MR, with each other, it was observed that all correlation coefficients obtained were $<0.7$. Therefore, all of these variables were included in the linear regression analysis.

Table 2: Mean, median, minimum, and maximum values of dependent and independent variables

\begin{tabular}{lll}
\hline Variables & Turkey & $\begin{array}{l}\text { Median of provincial data } \\
\text { (min-max) }\end{array}$ \\
\hline Infant mortality rate & 9.1 & $8.5(3.0-16.2)$ \\
Under-five mortality rate & 11.2 & $10.6(3.0-19.6)$ \\
GDP per capita (thousand TL) & 52.3 & $36.8(16.7-86.8)$ \\
Proportion of women aged $\geq 18$ with high school or higher education (percent) & 41.1 & $37.2(23.1-55.1)$ \\
Ratio of municipal population served by a sewerage network to total municipal population (\%) & 91 & $93(31.0-100.0)$ \\
Rural population ratio (percent) & 11.5 & $34.8(0.0-76.7)$ \\
Number of physicians per 100,000 people & 117 & $156.9(104.3-310.1)$ \\
Population per family medicine unit & 3141 & $3095(2679-3430)$ \\
Number of hospital beds per 100,000 people & 286 & $264(119-506)$ \\
Number of newborn intensive care beds per thousand births & 5.3 & $5.6(1.2-14.6)$ \\
Total fertility rate (per thousand) & 1.9 & $1.7(1.3-3.9)$ \\
Ratio of adolescent births to total births (percent) & 0.8 & $0.69(0.1-2.7)$ \\
\hline
\end{tabular}

GDP: gross domestic product

Table 3: Correlation matrix for dependent and independent variables

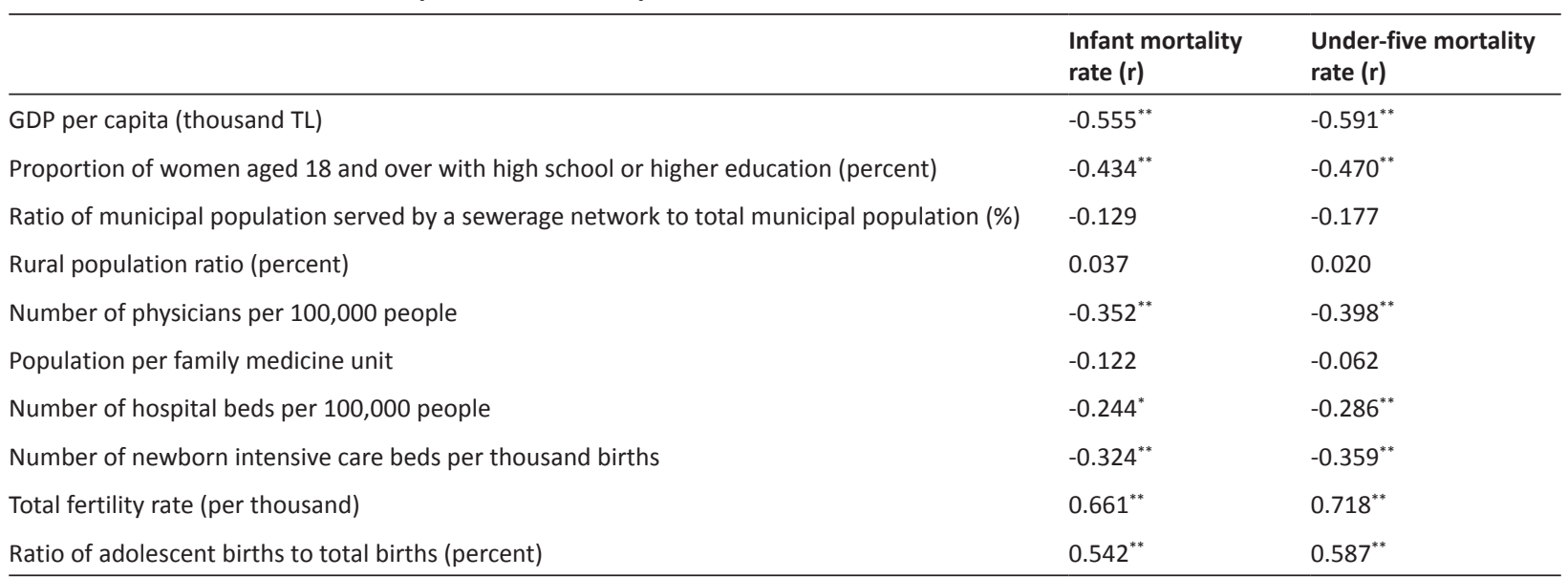

*:p<0.05, **: p<0.01 GDP: gross domestic product 
In the bivariate regression analysis of the natural logarithm of IMR, it was found that the individual effects of all independent variables, except for the number of hospital beds per 100,000 people, on the models were statistically significant. However, in the bivariate regression analysis of the natural logarithm of U5MR, the effects of all individual variables on the model were found to be statistically significant (Table 4).

The only variable that had a statistically significant effect on the multivariate model created for IMR was the total fertility rate. According to the model, it was found that each unit increase in the total fertility rate caused an increase of 0.621 units in the natural logarithm of IMR (Standardized $\beta=0.621$ ). Total fertility rate could explain $38.5 \%$ of the change in IMR $\left(R^{2}=0.385\right)$. The only variable that had a statistically significant effect on the multivariate model created for U5MR was, again, the total fertility rate. Based on the model, each unit increase in the total fertility rate caused an increase of 0.667 units in the natural logarithm of U5MR (Standardized $\beta=0.667$ ). Total fertility rate could explain $44.5 \%$ of the change in U5MR $\left(R^{2}=0.445\right)$ (Table 4$)$.

Figure 1 shows the variation in IMR with respect to the total fertility rate, and Figure 2 shows the variation in U5MR with respect to the total fertility rate.

Table 4: Linear regression analysis of factors associated with natural logarithms of infant mortality rate and under-five mortality rate

\begin{tabular}{|c|c|c|c|}
\hline & Standardized $\beta$ & p & $\mathbf{R}^{2}$ \\
\hline \multicolumn{4}{|l|}{ Bivariate models for the natural logarithm of IMR } \\
\hline GDP per capita (thousand TL) & -0.422 & $<0.001$ & 0.178 \\
\hline Proportion of women aged $\geq 18$ with high school or higher education (percent) & -0.401 & $<0.001$ & 0.160 \\
\hline Number of physicians per 100,000 people & -0.295 & $<0.01$ & 0.087 \\
\hline Number of hospital beds per 100,000 people & -0.201 & $>0.05$ & 0.040 \\
\hline Number of newborn intensive care beds per thousand births & -0.286 & $<0.05$ & 0.082 \\
\hline Total fertility rate (per thousand) & 0.621 & $<0.001$ & 0.385 \\
\hline Ratio of adolescent births to total births (percent) & 0.468 & $<0.001$ & 0.219 \\
\hline \multicolumn{4}{|l|}{ Multivariate model for the natural logarithm of IMR } \\
\hline Total fertility rate & 0.621 & $<0.001$ & 0.385 \\
\hline \multicolumn{4}{|l|}{ Bivariate models for the natural logarithm of U5MR } \\
\hline GDP per capita (thousand TL) & -0.450 & $<0.001$ & 0.202 \\
\hline Proportion of women aged 18 and over with high school or higher education (percent) & -0.435 & $<0.001$ & 0.189 \\
\hline Number of physicians per 100,000 people & -0.333 & $<0.01$ & 0.111 \\
\hline Number of hospital beds per 100,000 people & -0.240 & $<0.05$ & 0.058 \\
\hline Number of newborn intensive care beds per thousand births & -0.341 & $<0.01$ & 0.116 \\
\hline Total fertility rate (per thousand) & 0.667 & $<0.001$ & 0.445 \\
\hline Ratio of adolescent births to total births (percent) & 0.489 & $<0.001$ & 0.240 \\
\hline \multicolumn{4}{|l|}{ Proportion of women aged 18 and over with high school or higher education (percent) } \\
\hline \multicolumn{4}{|l|}{ Multivariate model for the natural logarithm of U5MR } \\
\hline Total fertility rate & 0.667 & $<0.001$ & 0.445 \\
\hline
\end{tabular}

GDP: gross domestic product

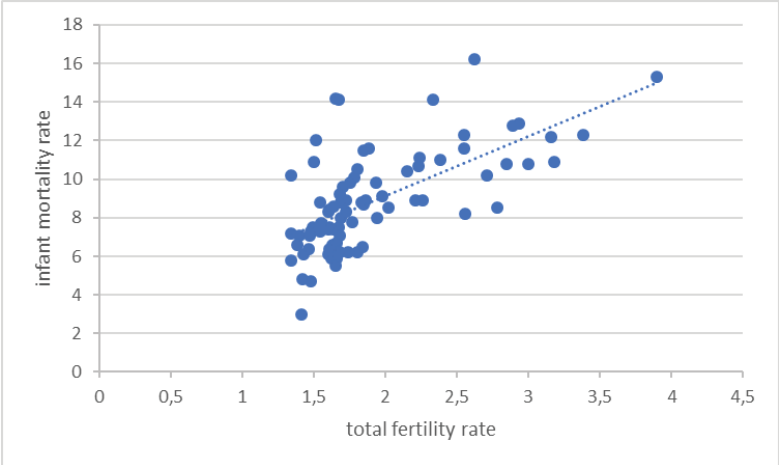

Figure 1: Variation of infant mortality rate according to total fertility rate

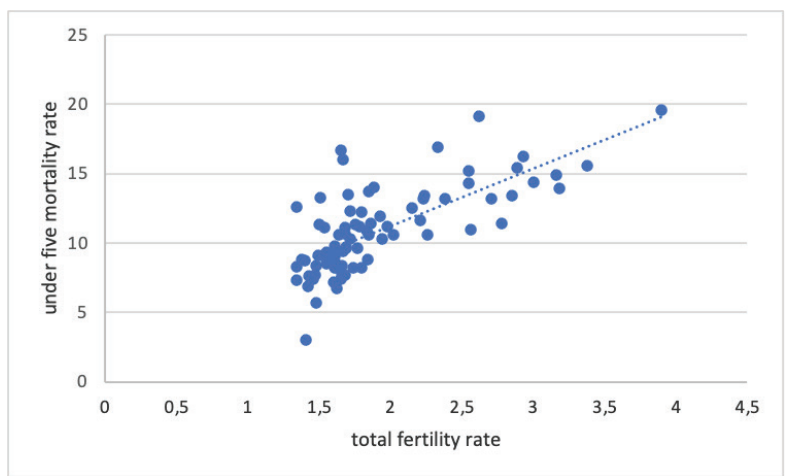

Figure 2: Variation of under-five mortality rate according to total fertility rate 


\section{DISCUSSION}

Although Turkey seems to perform relatively well compared to the rest of the world, the decline needs to continue in order to reduce the current IMR to 3.2 per thousand and U5MR to 3.9 per thousand, as in the EU (4). In terms of the efforts made regarding this issue, it would be instructive to determine the factors related to IMR and U5MR taking into account the country as a whole.

The "Infant Mortality Monitoring System" was established in Turkey in order to monitor all infant deaths, determine their causes, and take the relevant precautions. Since 2014, the infant mortality monitoring system has been integrated with the "Death Notification System," where all deaths are recorded at the national level. All cases of stillbirth and infant death are examined by the "Provincial Investigation Boards" established by the Provincial Health Directorates (23). However, there is no publicly available national report on the causes of infant mortality and factors associated with infant mortality based on these data.

\section{Total fertility rate and infant/child mortality}

It has been observed that TFR has a moderate positive relationship with IMR, and a strong positive relationship with U5MR. TFR stands out as the only parameter whose effect on the multivariate model is statistically significant. In different ecological studies, TFR has been found to be associated with IMR and U5MR. According to a study conducted with data from 181 countries, TFR was the variable with the strongest effect in the bivariate models created for IMR (24). In a study involving 46 least developed countries, TFR was among the factors found to have an effect in the multivariate model for U5MR (25). TFR was also among the factors affecting IMR in a multivariate model from a study conducted in Brazil (22).

In Turkey, TFR shows a significantly declining trend to such an extent that while it was 2.38 in 2001, it decreased to 1.76 in 2020. In addition, when a comparison was made for the TFR data from 2019, it was found that TFR was 1.86 in Turkey while it was 1.86 in France, which has the highest value in the EU, and 1.14 in Malta, which has the lowest value in the EU, and that the average value for EU-27 was 1.53 (26).

The relationship between high fertility and infant and child mortality has been clearly demonstrated through various assessments in TDHSs. According to TDHS 2013, while IMR was 17 per thousand for the $1^{\text {st }}$ birth, it is 15 per thousand for the $2^{\text {nd }}-3^{\text {th }}$ births, 22 per thousand for $4^{\text {th }}-6^{\text {th }}$ births, and 32 per thousand for $7^{\text {th }}$ or higher birth orders (3). U5MR was 19 per thousand for the first birth and for the $2^{\text {nd }}-3^{\text {th }}$ birth orders, 25 per thousand for the $4^{\text {th }}-6^{\text {th }}$ births, and 33 per thousand for the $7^{\text {th }}$ and higher birth orders (3). In the TDHS 2018 report, the risk ratio was calculated for each high-risk category by comparing the rate of deaths among births in this category with the rate of deaths among births that were not in any high-risk category. Accordingly, among the single risk categories, the risk ratio for higher than third birth order was 1.23. The births in this category constituted $7.1 \%$ of the total births examined. Among the multiple high-risk categories, the highest risk ratio was 2.31, which was calculated for birth intervals of $<24$ months and for birth orders more than third (27).

However, a gap between the current fertility status and the required fertility level in Turkey remains. It has been found that $14.8 \%$ of all births are not wanted and $10.6 \%$ of all births are earlier than wanted. Although TFR was 2.3 , the wanted TFR was 2.0 according to TDHS 2018 (27). The unmet need for family planning, which is another aspect of the issue, was $15 \%$ in TDHS 1993, while it tended to decrease over time and fell to $6 \%$ in TDHS 2013. It is noteworthy that it reached $12 \%$ with a 100\% increase in TDHS 2018 (27). Moreover, according to a study based on a separate sample representing Syrian migrants under temporary protection in Turkey, $21 \%$ of women had unmet family planning needs (28). However, the decisions made at the Nairobi Summit held at the $25^{\text {th }}$ anniversary of the International Conference on Population and Development and the Sustainable Development Goals envisage that the unmet need for family planning should be reduced to zero for everyone (29).

In addition, reproductive healthcare services were also among the healthcare services whose provision was negatively affected by the COVID-19 pandemic. An estimated 10\% reduction in the supply of modern family planning methods worldwide was noted, resulting in an increase of 49 million in the number of women who have unmet family planning needs worldwide (30). In a report prepared by the Family Health and Planning Foundation of Turkey, it was indicated that the stocks of contraceptive materials in public health institutions were depleted and new materials could not be provided during the pandemic period. It was reported that access to contraceptive methods might be a factor leading to an increase in unwanted pregnancies during this period $(31,32)$. The results of our study on the relationship between TFR and IMR raise the concern that an increase in infant mortality may be among the longterm adverse consequences of the pandemic.

TFR can explain $38.5 \%$ of the change in IMR and $44.5 \%$ of the change in U5MR in multivariate models. Factors that may explain the remaining variation in IMR and U5MR are other independent variables that are not included in the multivariate model. In a study conducted in Brazil, the $\mathrm{R}^{2}$ values were found to be 0.36 and 0.32 in the multivariate models created for the years 1991 and 2000, respectively (22). These data indicate that IMR and U5MR are dependent variables that may be associated with many factors. The fact that many factors with significant effects were found in the bivariate model in our study also supports this assessment.

\section{Adolescent fertility and infant/child mortality}

Another parameter related to fertility, which was found to be associated with IMR and U5MR in our study, was the ratio of adolescent births to total births. It is known that adolescent mothers have more adverse pregnancy outcomes and higher maternal death than non-adolescent mothers (27). In an ecological study evaluating 192 countries, the adolescent 
fertility rate was among the variables found to be associated with IMR in the bivariate analysis (33).

Adolescent pregnancies remain among the issues that require intervention in Turkey. According to TDHS 2018, 2.8\% of adolescents (15-19 years of age) had a live birth, and about $1 \%$ of them were pregnant with their first child during the study. However, $10 \%$ of women aged 19 already gave birth to their first child or were pregnant (27). Developing initiatives to prevent adolescent pregnancies will also contribute to reducing infant and child mortality.

\section{Income and infant/child mortality}

In this study, a moderate negative correlation was found between GDP per capita and IMR and U5MR. While GDP per capita has an effect in the bivariate model, it does not have any effect in the multivariate model. There are studies that include data from different countries and show that IMR decreases as per capita income increases in multivariate models. One of these studies is an ecological study evaluating 192 countries using data from the World Bank, and there is another ecological study that includes data from 152 countries with low, medium, and high development levels $(33,34)$. In a study conducted with the data of 181 countries from 2015, similar to our study, per capita income was one of the factors found to have an effect on IMR in the univariate model (24). Based on the examples at the country level, it was found that income level had a significant effect in the multivariate models in Brazil and India, while it had a significant effect in the univariate model in Italy $(22,35,36)$. Income is among the variables that are also associated with U5MR in groups of countries at different levels of development. In a study involving OECD countries, U5MR was associated with GDP per capita in a multivariate model (37). Per capita income was also found to be associated with U5MR in a multivariate model in an ecological study involving 46 least developed countries (25).

In an ecological study based on data from 2007 for Turkey, GDP per capita was among the variables that were found to have an effect on the model for both IMR and U5MR in the univariate model (16). It has been observed that income is associated with IMR and U5MR in a multivariate model in some ecological studies, and in a univariate model, similar to our study, in others. However, based on the household welfare level, IMR ranged from 23 per thousand in the lowest group to 8 per thousand in the highest group, and U5MR ranged from 28 per thousand in the lowest group to 8 per thousand in the highest group in TDHS 2013 (3). The relationship between income and infant and child mortality, which has been demonstrated many times at the national and international levels, reveals that socioeconomic determinants of health affect people's lives starting from the mother's womb in a way that can have fatal consequences.

\section{Education and infant/child mortality}

Another socioeconomic variable that was found to be negatively associated with IMR and U5MR in the study is the proportion of women with high school or higher education. In different studies, the education level of women was found to be associated with IMR. In a study that included data from 152 countries, the proportion of illiterate women was associated with IMR in a multivariate model (34). In other studies that include country data, a relationship was found between IMR and the number of years women went to school $(24,33)$.

Education-related parameters were among the variables found to have an effect in both ecological studies conducted so far regarding the issue in the national literature for Turkey. According to the results of an ecological study based on provincial data from Eskişehir, the only factor affecting the model for logarithmic IMR in multivariate linear regression analysis is the proportion of women who did not go to school (standardized $\beta=0.589, R^{2}=0.566$ ) (15). In an ecological study based on data from 2007 for Turkey, the rate of illiterate women was among the factors found to have a significant effect in the multivariate model for both IMR and U5MR (16).

According to TDHS 2013, it was found that IMR varied from 26 per thousand in the no/incomplete education group to 9 per thousand in the high school and above group, and U5MR from 30 per thousand in the no/incomplete education group to 12 per thousand in the high school and above group (3). Studies have revealed that prevention of infant and child mortality would be among the results obtained through the multiplier effect of the education of girls.

\section{Provision of healthcare services and infant/child mortality}

In our study, the variables that were found to have a weak negative relationship with IMR and U5MR were the number of physicians per 100,000 people, the number of hospital beds per 100,000 people, and the number of newborn intensive care beds per thousand births. In an ecological study based on data from 2007 for Turkey, the variables that had an effect on the model for both IMR and U5MR included the population per physician, the population per community health center, and the number of beds per ten thousand people for the univariate model (16). However, it has been observed that the studies that found a relationship between the variables related to healthcare service provision and child mortality were conducted mostly in developing countries (38-40). The weak relationship with the parameters related to healthcare service provision in our study indicates that their effects are indirect. This result is pleasing in terms of the adequacy of the healthcare service capacity in Turkey. However, it should be noted that inadequacies on a provincial basis may have an effect.

\section{Limitations}

The variables included in the model in this study include data that can be obtained from TURKSTAT and the Ministry of Health on a provincial basis. The number of parameters included in the model is a limitation of this study. In the literature, there are other parameters that have been found to be associated with IMR or U5MR, in addition to the variables included in our study. For example, a relationship has been found between IMR and the rate of health expenditures in Brazil, the Gini coefficient 
and unemployment rate in Italy, and the unemployment rate in India $(22,35,36)$. In studies evaluating different countries collectively, the variables associated with IMR included access to drinking water, immunization rate, maternal mortality rate, out-of-pocket health expenditures, per capita health expenditures, and the Gini coefficient $(33,34,41)$. In a study involving sub-Saharan African countries, the factors associated with U5MR included immunization rate, access to healthy drinking water, and Gini coefficient (38).

This study is an ecological study. As an epidemiological study type, ecological studies have certain disadvantages in addition to their advantages. "Ecological fallacy" or "ecological bias" refer to the differences between studies based on individual data and ecological data. Ecological bias occurs due to different intra-group distributions of independent variables and confounders, whose effects are being investigated, in different groups (12). The reason for ecological bias is that the relationship between variables observed at the group level is not necessarily representative of the relationship at the individual level (14).

In the stepwise selection method, which is one of the variable selection methods used in linear regression analysis, the aim is to select the variables that are not related to each other and that affect the dependent variable to the greatest extent after determining the independent variables that can affect the dependent variable. The most important benefit of the stepwise selection method is that it resolves the multicollinearity problem arising from the possible correlation between the independent variables included in the model (42). In this study, in order to reduce the effect of the multicollinearity problem, the variables that were found to be strongly correlated with each other in the correlation analysis (the ones with a correlation coefficient higher than 0.7) were not included together in the model. For the same purpose, the stepwise regression method was used in the linear regression analysis. However, in our study, multicollinearity may have played a role in the fact that the variables that were found to have a significant effect in the bivariate model were not significant in the multivariate model (43). Considering the studies conducted, it may be observed that many variables are associated with IMR or U5MR in bivariate analyses, whereas the number of associated parameters is less in number in multivariate analyses. In some ecological studies, similar to our study, the effect of only one variable was found to be significant in the multivariate model. Literacy rate among women in India and unemployment rate in Italy were the only variables found to be significant for IMR, and adult literacy rate was the only significant variable for U5MR in a study involving countries that include Turkey $(35,36,41)$.

\section{CONCLUSION AND RECOMMENDATIONS}

Factors that were found to be associated with IMR and U5MR included factors associated with fertility preferences such as TFR and adolescent births, socioeconomic factors such as income and education level, and factors associated with healthcare service provision such as the number of physicians and number of beds. When the correlation coefficients are examined, it may be observed that the strongest relationship is with variables related to fertility preferences, followed by socioeconomic variables, and the variables related to service provision have the weakest relationship. In the multivariate model, the only variable with a significant effect was TFR. Accordingly, intervention policies for infant and child mortality should primarily focus on health promotion programs aiming for appropriate changes in individuals' health-related behaviors regarding high fertility preferences and initiatives aimed at reducing socioeconomic inequalities. However, initiatives should be developed to prevent adolescent marriages. It appears that approaches that prioritize solving the problem only with initiatives to improve healthcare service provision would only be making an effort for relatively indirect causes.

It may be useful to identify new interventional aspects with studies on the determinants of fertility preferences. The effect of TFR demonstrates the importance of the unmet need for family planning. It should be borne in mind that interruptions in reproductive health services in the post-pandemic period will be a potential factor for an increase in IMR.

The fact that income and education are associated with IMR and U5MR in bivariate analyses has revealed the severe consequences of inequalities in health. Economic policies aimed at correcting income inequalities and initiatives to increase girls' education levels will lead to life-saving outcomes for infants and children.

Etik Komite Onayı: Bu ekolojik çalışmada halka açık veri setleri kullanıldığından, çalışma etik kurul onayı kapsamı dışındadır.

Bilgilendirilmiş Onam: Katılımcılardan bilgilendirilmiş onam alınmıştır.

Hakem Değerlendirmesi: Dış bağımsız.

Çıkar Çatışması: Yazarlar çıkar çatş̧ması beyan etmemişlerdir.

Finansal Destek: Yazarlar finansal destek beyan etmemişlerdir.

Ethics Committee Approval: Since public datasets were used in this ecological study, it is outside the scope of ethics committee approval.

Informed Consent: Written consent was obtained from the participants.

Conflict of Interest: Authors declared no conflict of interest.

Financial Disclosure: Authors declared no financial support.

\section{REFERENCES}

1. World Health Organization. Children: improving survival and well-being: 2020 [updated 08.09.2020; cited 2021 01.08.2021]. Available from: https://www.who.int/en/news-room/fact-sheets/ detail/children-reducing-mortality.

2. World Health Organization. The Global Health Observatory: [cited 2021 01.08.2021]. Available from: https://www.who.int/data/gho/ data/themes/topics/indicator-groups/indicator-group-details/ GHO/infant-mortality. 
3. Hacettepe Üniversitesi Nüfus Etütleri Enstitüsü. 2013 Türkiye Nüfus ve Sağlık Araştırması. Ankara 2014

4. Sağıık Bakanlığı. Sağıık İstatistikleri Yıllığı 2019 Ankara 2021.

5. Theodore Tulchinsky, Varavikova E. Yeni Halk Sağlığı Palme Yayıncılık; 2018.

6. Ensure healthy lives and promote well-being for all at all ages: United Nations, Department of Economic and Social Affairs Sustainable 2021 [cited 2021 01.08.2021]. Available from: https:// sdgs.un.org/goals/goal3.

7. Sağıık Bakanlığı. Sağlık Bakanlığı 2019-2023 Stratejik Planı. Ankara 2019.

8. Burstein R, Henry NJ, Collison ML, Marczak LB, Sligar A, Watson $S$, et al. Mapping 123 million neonatal, infant and child deaths between 2000 and 2017. Nature 2019;574(7778):353-8. Epub 2019/10/18. doi: 10.1038/s41586-019-1545-0.

9. Social determinants of health: World Health Organization 2021 [cited 2021 02.07.2021]. Available from: https://www.who.int/ health-topics/social-determinants-of-health\#tab=tab_1.

10. Houweling TA, Kunst AE. Socio-economic inequalities in childhood mortality in low- and middle-income countries: a review of the international evidence. Br Med Bull 2010;93:7-26. Epub 2009/12/17.doi:10.1093/bmb/ldp048.PubMedPMID:20007188.

11. Gissler M, Alexander S, MacFarlane A, Small R, Stray-Pedersen $B$, Zeitlin J, et al. Stillbirths and infant deaths among migrants in industrialized countries. Acta Obstet Gynecol Scand 2009;88(2):13448. Epub 2008/12/20. doi: 10.1080/00016340802603805. PubMed PMID: 19096947.

12. Wakefield J. Ecologic studies revisited. Annu Rev Public Health 2008;29:75-90. Epub 2007/10/05. doi: 10.1146/annurev. publhealth.29.020907.090821. PubMed PMID: 17914933.

13. Morgenstern H. Ecologic studies in epidemiology: concepts, principles, and methods. Annu Rev Public Health 1995;16:61-81. Epub 1995/01/01. doi: 10.1146/annurev.pu.16.050195.000425. PubMed PMID: 7639884.

14. Metintaş S, Emrah A. Dermatolojik Hastaliklarda Araştirma Yöntemleri. ESTÜDAM Halk Sağlığı Dergisi 2019;4:1-26.

15. Metintas S, Arikan I, Fidan H, Kalyoncu C, Goktepe M. Identification of variables affecting infant mortality rate in Eskisehir (Turkey). Pakistan Journal of Medical Sciences 2010;26(1).

16. Semra Ay EE, Cemil Özcan Türkiye'de kadın ve çocuk sağı̆ı̆ı ile ilgili bazı ölçütler ile sosyo-ekonomik degişkenler arasındaki ilişki: Bir ekolojik çalışma. Toplum ve Hekim 2004;19(2):83-91.

17. TÜik. Merkezi Dağıtım Sistemi 2021 [cited 2021 21.05.2021]. Available from: https://biruni.tuik.gov.tr/medas/?locale=tr.

18. TÜik. IIl Göstergeleri Gösterge Uygulaması 2021 [cited 2021 21.05.2021]. Available from: https://biruni.tuik.gov.tr/ ilgosterge/?locale=tr.

19. Kamu Hastaneleri Genel Müdürlüğü. Kamu Hastaneleri İstatistik Raporu 2017. Ankara 2018.

20. Akoglu H. User's guide to correlation coefficients. Turk J Emerg Med 2018;18(3):91-3. Epub 2018/09/08. doi: 10.1016/j. tjem.2018.08.001. PubMed PMID: 30191186; PubMed Central PMCID: PMCPMC6107969.

21. Ratner $B$. The correlation coefficient: Its values range between+ 1/- 1 , or do they? Journal of Targeting, Measurement and Analysis for Marketing 2009;17(2):139-42.
22. Bezerra Filho JG, Pontes LR, Miná Dde L, Barreto ML. Infant mortality and sociodemographic conditions in Ceará, Brazil, 1991 and 2000. Rev Saude Publica. 2007;41(6):1023-31. Epub 2007/12/11. doi: 10.1590/s0034-89102007000600018. PubMed PMID: 18066472.

23. Sağlık Bakanlığı Halk Sağlığı Genel Müdürlüğü. Bebek Ölümleri İzleme Sistemi [cited 2021 21.08.2021]. Available from: https://hsgm.saglik.gov.tr/tr/cocukergen-bois-liste/bebek\%C3\%B6l\%C3\%BCmleri-izleme-sistemi.html.

24. Khazaei S, Ayubi E, Nematollahi S. Variations of infant and underfive child mortality rates around the world, the role of human development index (HDI). International Journal of Pediatrics. 2016;4(5):1671-7.

25. Chuang YC, Sung PW, Chao HJ, Bai CH, Chang CJ. A longitudinal ecological study of the influences of political, economic, and health services characteristics on under-five mortality in less-developed countries. Health Place. 2013;23:111-21. Epub 2013/07/09. doi: 10.1016/j.healthplace.2013.05.007. PubMed PMID: 23832128.

26. TÜiK. Doğum İstatistikleri 2020. [cited 01.07.2021]. Available from: https://data.tuik.gov.tr/Bulten/Index?p=DogumIstatistikleri-2020-37229

27. Hacettepe Üniversitesi Nüfus Etütleri Enstitüsü. 2018 Türkiye Nüfus ve Sağlık Araştırması. Ankara, 2019.

28. Hacettepe Üniversitesi Nüfus Etütleri Enstitüsü. 2018 Türkiye Nüfus ve Sağlık Araşttrması Suriyeli Göçmen Örneklemi. Ankara, 2019.

29. Hacettepe Üniversitesi Nüfus Etütleri Enstitüsü. Türkiye'de Karşılanmamış Aile Planlaması İhtiyacı Küresel Hedefler Yerel Koşullar Ankara 2020. Available from: http://www.hips.hacettepe. edu.tr/TR_karsilanmamis_aile_planlamasi.pdf

30. Riley T, Sully E, Ahmed Z, Biddlecom A. Estimates of the Potential Impact of the COVID-19 Pandemic on Sexual and Reproductive Health In Low- and Middle-Income Countries. Int Perspect Sex Reprod Health. 2020;46:73-6. Epub 2020/04/29. doi: 10.1363/46e9020. PubMed PMID: 32343244.

31. Günay T. COVID-19 Pandemisinde Cinsel Sağlık ve Üreme Sağlığı Ankara: Türk Tabipleri Birliği, 2021.

32. Türkiye Aile Sağlığı ve Planlaması Vakfi. Pandemi Öncesi ve Sırasında Türkiye'de Cinsel Sağlık ve Üreme Sağlığı Hizmetleri İzleme Raporu İstanbul 2021.

33. Sartorius BK, Sartorius K. Global infant mortality trends and attributable determinants-an ecological study using data from 192 countries for the period 1990-2011. Population Health Metrics. 2014;12(1):1-15.

34. Schell CO, Reilly M, Rosling H, Peterson S, Ekström AM. Socioeconomic determinants of infant mortality: a worldwide study of 152 low-, middle-, and high-income countries. Scand J Public Health. 2007;35(3):288-97. Epub 2007/05/29. doi: 10.1080/14034940600979171. PubMed PMID: 17530551.

35. Dallolio L, Di Gregori V, Lenzi J, Franchino G, Calugi S, Domenighetti $\mathrm{G}$, et al. Socio-economic factors associated with infant mortality in Italy: an ecological study. International journal for equity in health. 2012;11(1):1-5.

36. Mukherjee A, Bhattacherjee S, Dasgupta S. Determinants of infant mortality in rural India: An ecological study. Indian journal of public health. 2019;63(1):27.

37. Chung $\mathrm{H}$, Muntaner $\mathrm{C}$. Political and welfare state determinants of infant and child health indicators: an analysis of wealthy countries. Soc Sci Med. 2006;63(3):829-42. Epub 2006/04/01. doi: 10.1016/j. socscimed.2006.01.030. PubMed PMID: 16574291. 
38. Olafsdottir AE, Reidpath DD, Pokhrel S, Allotey P. Health systems performance in sub-Saharan Africa: governance, outcome and equity. BMC Public Health 2011;11:237. Epub 2011/04/19. doi: 10.1186/1471-2458-11-237. PubMed PMID: 21496303; PubMed Central PMCID: PMCPMC3095561.

39. Kipp AM, Blevins M, Haley CA, Mwinga K, Habimana P, Shepherd $\mathrm{BE}$, et al. Factors associated with declining under-five mortality rates from 2000 to 2013: an ecological analysis of 46 African countries. BMJ Open 2016;6(1):e007675. Epub 2016/01/10. doi: 10.1136/bmjopen-2015-007675. PubMed PMID: 26747029; PubMed Central PMCID: PMCPMC4716228.

40. Marinho C, Flor TBM, Pinheiro JMF, Ferreira MÂ F. Millennium Development Goals: the impact of healthcare interventions and changes in socioeconomic factors and sanitation on under-five mortality in Brazil. Cad Saude Publica 2020;36(10):e00191219. Epub 2020/10/22. doi: 10.1590/0102-311x00191219. PubMed PMID: 33084833.
41. Mirzazadeh A, Holakouie Naieni K, Rashidian A, Vazirian P, Moradi G, Malekafzali H. Millennium Development Goal Four; Child and Infant Mortality, Achievements in Economic Cooperation Organization Countries: An Ecological Study. Journal of Comprehensive Pediatrics 2013;4(2):99-104.

42. Kayaalp GT, Güney MÇ, Cebeci Z. Çoklu doğrusal regresyon modelinde değişken seçiminin zootekniye uygulanışı. Çukurova Üniversitesi Ziraat Fakültesi Dergisi 2015;30(1):1-8.

43. Gökgöz F. Çoklu Doğrusalıı Sorunu Ankara Üniversitesi 2021 [cited 2021 01.07.2021]. Available from: https://acikders.ankara. edu.tr/pluginfile.php/130808/mod_resource/content/0/7-\%20 \%C3\%87oklu\%20do\%C4\%9Frusall\%C4\%B1k.pdf. 